IJABBR-2017- eISSN: 2322-4827

International Journal of Advanced Biological and Biomedical Research 5(1) (2017) 41-47

Journal homepage: www.ijabbr.com

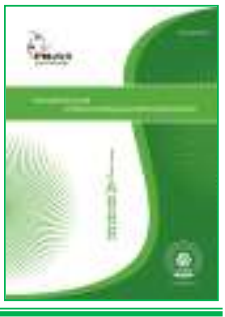

Research Article

DOI: 10.18869/IJABBR.2017.405

\title{
Efficacy of Rhinoceros Beetle (Xylotrupes Gideon) Nano Chitosan and Calcium Mouthwash in Reducing Quantity Oral Cavity Bacteria among Elementary School Age Children
}

\author{
Ade Komariah*, Roberto A Tatara, Del A Bustami \\ Department of Oral Biology, Faculty of Dentistry, University of Trisakti Jakarta 11440, Indonesia
}

\section{ART I C L E IN F O}

\section{Article history:}

Received: 14 Jan 2017

Revised:23 Feb2017

Accepted: 27 Mar 2017

ePublished: 30 Apr 2017

\section{Key words:}

Mouthwash

Nano chitosan

Nano calcium

Bacterial quantity

\section{A B S T R A C T}

Objective: The level of dental and oral hygiene on elementary school age children is very low, so it can be increasing the incidence of dental and oral diseases which caused by various microorganisms. Mouthwash can keeping dental and oral hygiene, but many commercial mouthwash is still used alcohol as their ingredients, which can be giving side effects, therefore, we still needed used alternative mouthwash, which made from nano chitosan and nano calcium, derived from nature Xylotrupes Gideon. Methods: This is a experimental study with pre and post test control group design using total plate count method. Total is 27 subjects, aged 9 years. Processing data is done by statistical test Chi Square, and one way ANOVA with software of SPSS 23. Results: Results showed that serum concentration of glucose, cholesterol and triglyceride were significantly higher ( $p$ $\leq 0.05$ ) when compared with the fluid from three follicles size categories (Small, Medium and large follicles in $\mathrm{CL}^{+}$and $\mathrm{CL}^{-}$ovaries). The differences between follicle size categories in $\mathrm{CL}^{-}$ovaries were only significant for concentrations of glucose and triglyceride. The FF concentration of glucose and cholesterol in same follicle size categories (Small, Medium and large follicles in $\mathrm{CL}^{+}$and $\mathrm{CL}^{-}$ovaries) were significant $(\mathrm{P} \leq 0.05)$. Conclusions: Measurement results the quantity of bacteria suggested that decreased of bacteria colonies before and after gargle, on negative control 30\%-73\%, positive control 33\%$100 \%$, the $250 \mathrm{ppm}$ concentration is $95 \%-100 \%, 500 \mathrm{ppm}$ and $750 \mathrm{ppm}$ concentration is $100 \%$. Nanoparticles of chitosan and calcium-based mouthwash formulation from $X$. gideon has the ability to reduce oral bacterial colonies quantity among elementary school age children. More high concentrations of mouthwash formulations which are used more low quantity of oral bacteria colonies.

\section{Introduction}

Chitosan is a natural biopolymer, polysaccharide liniershaped consists of $\beta$-(1-4)-linked D glucosamine and $\mathrm{N}$ acetyl-D-glucosamine (Puvvada et al., 2012). Chitosan can be isolated from the shells of crabs, shrimp and from the exoskeletons or insects kutikula (Bansal et al., 2011), such as beetle (Liu et al., 2012). X. gideon is a pest for human (Davis 2001). X. gideon is insects are found in
Southeast Asia, including in Indonesia. One alternative utilization efforts of this pest to be high economical product (Komariah, and Luki 2012). Chitosan can be applied to various purposes, because has several advantages (Yogeshkumar et al., 2013), such as the nature of a biocompatible, biodegradable and non-toxic (Sun and Li 2013). Chitosan obtained from natural resources with process was slightly longer than chitin (Goy et al., 2009). Results chitosan demineralization

${ }^{*}$ Corresponding Author: Ade Komariah, Department of Oral Biology, Faculty of Dentistry, University of Trisakti Jakarta 11440, Indonesia 
process can be produce nanoparticles calcium forms. Chitosan and calcium was very promising biomaterial to use in nanoparticles form.

The size of the used biomaterial become very important for an action active ingredients. On the size, the particles can be have properties and functions much differently than the same particles (Yah et al., 2012). Using nanoparticles materials offers big advantages because their unique size and physicochemical properties. Today nanoparticles study were growing rapidly because it can be applied to various field such as electronics, optical and biomedical (Stern and McNeil 2008). Nanoparticles seen as a highly promising carrier to improve the bioavailability from the biomolecules (Tiyaboonchai, 2003), because it has the better ability to diffuse and penetrate into mucosa layer (Sarmento et al., 2007). One alternative use nano chitosan is a material base moutwash formulations, because nano chitosan has a high antimicrobial activity (Mirhashemi et al., 2013).

According to Survei Kesehatan Rumah Tangga (SKRT) by Ministry of Health RI in 2011, suggested that the dental and oral disease is a $6^{\text {th }}$ highest disease among Indonesian society. It is evidenced by their $60 \%$ population of Indonesia is still experiencing dental and oral disease. The oral cavity was not homogenous environment, because mucosal and tooth surface was different as well as the warm temperature, moisture and rich nutrients envireonment that can be increase the growth of microorganisms, so it can lead to the infection (Batabyal et al., 2012). Oral cavity has a normal flora that is generally not pathogenic and have stable relationship with the host (Majumdar and Singh 2014), but on specific conditions such as when decreased immune system occur, normal flora can be transformed into a pathogen. Bacterial species which can be found in children's oral cavity such as, Streptococcus sanguis (Yamaguchi et al., 2006), Staphylococcus spp. (Law et al., 2007), Veillonella spp. (Mashima et al., 2015), Neisseria spp. (Liu et al., 2012), Actinomyces spp. (Darout 2014), and Lactobacilli spp (Klais et al., 2005).

Among elementary school age children, dental and oral hygiene is very low, because lack of parents and teachers supervision about how to consume sweets foods as well as minimal children knowledge level about how to maintain good oral cavity hygiene. Dental and oral hygiene all this time performed with brush your teeth, but to some cases, such as dental and gums disease mouthwash use is very important. Gargle with mouthwash can eliminates bacteria in the teeth which are not reached by the toothbrush (Schaeffer et al., 2011). Use antiseptic mouthwash is a one measure to keeping oral and dental hygiene, but some mouthwash was used now are currently using alcohol as an antibacterial, alcohol in mouthwash can lead to oral cancer (Farah et al., 2009). By looking at the problems that exist, it is necessary to find alternative mouthwash derived from natural ingredients and does not cause negative effects on the body. One of the latest breakthrough by creating a mouthwash products containing nano chitosan as an antimicrobial and nano calcium as an addition to the tooth mineral. The use of mouthwash nano chitosan and nano calcium is effectively used in children of school age, with the level of knowledge of children about oral hygiene are low, consumption of sweet foods in excess, as well as a desire to brush their teeth is low, then the use of mouthwash that is keeping (mouthcare) with a combination of nano chitosan and nano calcium can reduce the quantity of colonies of bacteria in the oral cavity and as an amplifier of teeth in children.

\section{Methods}

This study was a laboratory experimental design with pre and post test control group design. Calcium and chitosan as raw material medicine formulations derived from demineralization, deproteinization, decolorization, deacetylation of exoskeletons $X$. gideon from Bogor Barat Indonesia, which has undergone physical modifications become nano chitosan and nano calcium. This study is divided into second phases: first stage by formulating mouthwash and second phases is test the quantity of bacteria in the oral cavity of elementary school children by using total plate count method.

\section{Chitosan nano and nano calcium}

Preparation $X$. gideon with the destruction of the exoskeleton after drying, do demineralization, deproteinization, decolorization and deacetylation process to obtain the chitosan. Manufacture of nano chitosan by ionic gelation method using a magnetic stirrer. Nano calcium obtained through the precipitation process of demineralization results chitosan.

\section{Total plate count}

Total plate count testing done by taking gargle results before and after of a public elementary school students 07 Grogol Jakarta, the number of subjects was calculated using the formula Federer (1963), thus obtained the number of subjects by 27 people at the age of 9 years.

\section{Statistic analysis}

Data processing is done by chi-square test and one way ANOVA with SPSS 23 and Microsoft Excel.

\section{Results \\ Overview Population Distribution}

Distribution of oral conditions on the respondents in this research show the majority of children have high levels of good oral hygiene by $51.85 \%$, moderate $29.62 \%$, and poor of $18.51 \%$ (Figure 1). 


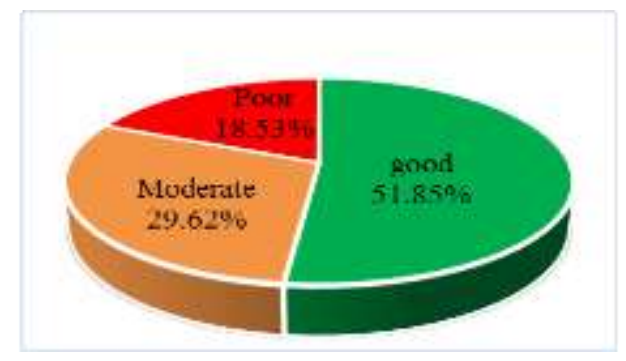

Fig. 1: Distribution of oral cavity respondent condition

The relationship between the level of oral hygiene by sex shows 15 (55.55\%) of children with sex male has a poor level of oral hygiene as much as $3(11.12 \%), 5$ (18:51\%) moderate, and 7 (25.92\%) good, Distribution of female of $12(44.45 \%)$ children with good oral hygiene level was 7 (25.92\%), 3 (11.12\%) moderate, and 2 (7:41\%) poor.

Based on brushing habits with the level of oral hygiene showed of $19(70.37 \%)$ children have a habit of brushing teeth twice a day with the poor level of oral hygiene is 4 (14.81\%), moderate $4(14.81 \%)$ and good was 11 $(40.74 \%)$. In brushing more than twice a day to the level of oral hygiene as much as $8(29.63 \%)$ of children have high levels of poor oral hygiene is $1(3.70 \%)$, moderate is $4(14.81 \%)$ and good is $3(11.11 \%)$.

Based on the level of knowledge to the level of oral hygiene showed $14(51.85 \%)$ children have a good oral hygiene level due to have a good level of knowledge in oral hygiene, including knowledge about the right time to brushing teeth, effect don't maintenance dental hygiene and the importance go to a dentist.

\section{Total Plate Count Test Results}

Quantity examination oral bacteria using total plate count test from gargle results representing the number of bacteria in the oral cavity present in saliva. Gargle from negative control is done with sterile aquadestilata, herbal mouthwash listerine as a positive control, and chitosan and calcium nanoparticles-based mouthwash formulations at concentration of $250 \mathrm{ppm}, 500 \mathrm{ppm}$ and $750 \mathrm{ppm}$, respectively.

The observation result of the effectiveness of mouthwash formulations done by counting the number of colonies on the first day to determine the number of bacterial colonies decrease in saliva on the next day, either in the negative control, positive and nanoparticles-based mouthwash formulations. Observations in the quantity decrease of oral bacteria colonies is done by calculating the difference in the number of bacterial colonies before and after the treatment. The observation result on the negative control can be seen in Table 1 .

Table 1: Efficacy aquadestilata in reducing quantity of oral bacterial colonies

\begin{tabular}{ccccccc}
\hline Total & \multicolumn{5}{c}{ Negative Control } \\
No & $\begin{array}{c}\text { Tacterial } \\
\text { colonies } \\
\text { before } \\
\text { gargle } \\
(\mathrm{CFU} / \mathrm{ml})\end{array}$ & $\begin{array}{c}\text { Bacterial } \\
\text { Colonies } \\
\text { after gargle } \\
\text { (CFU/ml) }\end{array}$ & $\begin{array}{c}\text { Bacterial } \\
\text { colonies } \\
\text { total } \\
\text { decrease } \\
(\text { CFU/ml) }\end{array}$ & $\begin{array}{c}\text { Total } \\
\text { Decrease of } \\
\text { Bacterial } \\
\text { Colonies in } \\
\text { Percent }(\%)\end{array}$ & $\begin{array}{c}\text { Total } \\
\text { Increase of } \\
\text { Bacterial } \\
\text { Colonies } \\
(\mathrm{CFU} / \mathrm{ml})\end{array}$ & $\begin{array}{c}\text { Total } \\
\text { increase } \\
\text { of } \\
\text { bacterial } \\
\text { colonies } \\
\text { in percent } \\
(\%)\end{array}$ \\
\hline N1 & 490 & 130 & 360 & 73 & 0 & 0 \\
N2 & 720 & 460 & 260 & 36 & 0 & 0 \\
N3 & 30 & 90 & 0 & 0 & 60 & 200 \\
N4 & 110 & 30 & 80 & 73 & 0 & 0 \\
N5 & 40 & 20 & 20 & 50 & 0 & 0 \\
N6 & 370 & 260 & 110 & 30 & 0 & 0 \\
\hline
\end{tabular}

The observation result of the effectiveness of mouthwash herbs Listerine (positive control) in reducing the quantity of oral bacterial colonies, by doing gargle using aquadestilata before gargle with mouthwash herbs listerine. The observation result are shown in Table 2.

Table 2. Efficacy herbs Listerine in reducing quantity of oral bacterial colonies

\begin{tabular}{|c|c|c|c|c|c|c|}
\hline \multirow[b]{2}{*}{ No } & \multicolumn{6}{|c|}{ Positive Control } \\
\hline & $\begin{array}{c}\text { Total } \\
\text { Bacterial } \\
\text { colonies } \\
\text { before } \\
\text { gargle } \\
(\mathrm{CFU} / \mathrm{ml})\end{array}$ & $\begin{array}{c}\text { Total } \\
\text { Bacterial } \\
\text { Colonies after } \\
\text { gargle } \\
(\mathrm{CFU} / \mathrm{ml})\end{array}$ & $\begin{array}{c}\text { Bacterial } \\
\text { colonies } \\
\text { total } \\
\text { decrease } \\
(\mathrm{CFU} / \mathrm{ml})\end{array}$ & $\begin{array}{c}\text { Total } \\
\text { Decrease } \\
\text { of } \\
\text { Bacterial } \\
\text { Colonies in } \\
\text { Percent } \\
(\%)\end{array}$ & $\begin{array}{c}\text { Total } \\
\text { Increase of } \\
\text { Bacterial } \\
\text { Colonies } \\
(\mathrm{CFU} / \mathrm{ml})\end{array}$ & $\begin{array}{c}\text { Total } \\
\text { increase of } \\
\text { bacterial } \\
\text { colonies in } \\
\text { percent (\%) }\end{array}$ \\
\hline P1 & 30 & 20 & 10 & 33 & 0 & 0 \\
\hline
\end{tabular}




\begin{tabular}{ccccccc} 
P2 & 240 & 0 & 240 & 100 & 0 & 0 \\
P3 & 110 & 0 & 110 & 100 & 0 & 0 \\
P4 & 130 & 10 & 120 & 92 & 0 & 0 \\
P5 & 380 & 10 & 370 & 97 & 0 & 0 \\
P6 & 60 & 10 & 50 & 83 & 0 & 0 \\
\hline
\end{tabular}

The observation of the effectiveness of nanoparticlebased mouthwash formulations in reducing the quantity of oral bacterial colonies, by using aquadestilata gargle before rinsing with nanoparticle-based formulation mouthwash concentration of $250 \mathrm{ppm}$. The observations result in the positive control group are shown in Table 3.

Table 3. Efficacy nanoparticle mouthwash formulations at $250 \mathrm{ppm}$ concentration in reducing quantity oral bacterial

\begin{tabular}{|c|c|c|c|c|c|c|}
\hline \multirow[b]{2}{*}{ No } & \multicolumn{6}{|c|}{ Concentration of $250 \mathrm{ppm}$} \\
\hline & $\begin{array}{c}\text { Total } \\
\text { Bacterial } \\
\text { colonies } \\
\text { before } \\
\text { gargle } \\
(\mathrm{CFU} / \mathrm{ml}) \\
\end{array}$ & $\begin{array}{c}\text { Total } \\
\text { Bacterial } \\
\text { Colonies } \\
\text { after } \\
\text { gargle } \\
(\mathrm{CFU} / \mathrm{ml}) \\
\end{array}$ & $\begin{array}{c}\text { Bacterial } \\
\text { colonies } \\
\text { total } \\
\text { decrease } \\
(\mathrm{CFU} / \mathrm{ml})\end{array}$ & $\begin{array}{c}\text { Total } \\
\text { Decrease of } \\
\text { Bacterial } \\
\text { Colonies in } \\
\text { Percent } \\
(\%) \\
\end{array}$ & $\begin{array}{c}\text { Total } \\
\text { Increase of } \\
\text { Bacterial } \\
\text { Colonies } \\
(\mathrm{CFU} / \mathrm{ml})\end{array}$ & $\begin{array}{c}\text { Total } \\
\text { increase of } \\
\text { bacterial } \\
\text { colonies in } \\
\text { percent } \\
(\%)\end{array}$ \\
\hline $\begin{array}{c}\text { K1- } \\
1\end{array}$ & 620 & 30 & 590 & 95 & 0 & 0 \\
\hline $\begin{array}{c}\mathrm{K} 1- \\
2\end{array}$ & 360 & 20 & 340 & 94 & 0 & 0 \\
\hline $\begin{array}{c}\mathrm{K} 1- \\
3\end{array}$ & 810 & 0 & 810 & 100 & 0 & 0 \\
\hline $\begin{array}{c}\mathrm{K} 1- \\
4\end{array}$ & 130 & 0 & 130 & 100 & 0 & 0 \\
\hline $\begin{array}{c}\mathrm{K} 1- \\
5\end{array}$ & 117 & 0 & 117 & 100 & 0 & 0 \\
\hline
\end{tabular}

Observation of the effectiveness of nanoparticle-based mouthwash formulations at concentrations of 500ppm in reducing the quantity of oral bacterial colonies, can be seen in Table 4.

Table 4.Efficacy nanoparticles mouthwash in reducing quantity oral bacterial colony at concentration of 500ppm

\begin{tabular}{|c|c|c|c|c|c|c|}
\hline \multirow[b]{2}{*}{ No } & \multicolumn{6}{|c|}{ Concentration of $500 \mathrm{ppm}$} \\
\hline & $\begin{array}{c}\text { Total } \\
\text { Bacterial } \\
\text { colonies } \\
\text { before } \\
\text { gargle } \\
(\mathrm{CFU} / \mathrm{ml})\end{array}$ & $\begin{array}{c}\text { Total } \\
\text { Bacterial } \\
\text { Colonies } \\
\text { after } \\
\text { gargle } \\
(\mathrm{CFU} / \mathrm{ml})\end{array}$ & $\begin{array}{c}\text { Bacterial } \\
\text { colonies } \\
\text { total } \\
\text { decrease } \\
(\mathrm{CFU} / \mathrm{ml})\end{array}$ & $\begin{array}{c}\text { Total } \\
\text { Decrease } \\
\text { of } \\
\text { Bacterial } \\
\text { Colonies in } \\
\text { Percent } \\
(\%)\end{array}$ & $\begin{array}{c}\text { Total } \\
\text { Increase of } \\
\text { Bacterial } \\
\text { Colonies } \\
(\mathrm{CFU} / \mathrm{ml})\end{array}$ & $\begin{array}{c}\text { Total } \\
\text { increase of } \\
\text { bacterial } \\
\text { colonies in } \\
\text { percent (\%) }\end{array}$ \\
\hline $\begin{array}{c}\mathrm{K} 2- \\
1\end{array}$ & 80 & 0 & 80 & 100 & 0 & 0 \\
\hline $\begin{array}{c}\mathrm{K} 2- \\
2\end{array}$ & 160 & 0 & 160 & 100 & 0 & 0 \\
\hline $\begin{array}{c}\mathrm{K} 2- \\
3\end{array}$ & 40 & 0 & 40 & 100 & 0 & 0 \\
\hline $\begin{array}{c}\mathrm{K} 2- \\
4\end{array}$ & 140 & 0 & 140 & 100 & 0 & 0 \\
\hline $\begin{array}{c}\mathrm{K} 2- \\
5 \\
\end{array}$ & 20 & 0 & 20 & 100 & 0 & 0 \\
\hline
\end{tabular}


The observation result in reducing the quantity of oral bacterial colonies in the treatment group using nanoparticle-based mouthwash formulations at concentration of 750ppm can be seen in Table 5.

Table 5. Efficacy nanoparticles mouthwash in reducing quantity oral bacterial colony at concentration of 750ppm

\begin{tabular}{|c|c|c|c|c|c|c|}
\hline \multirow[b]{2}{*}{ No } & \multicolumn{6}{|c|}{ Concentration of $750 \mathrm{ppm}$} \\
\hline & $\begin{array}{c}\text { Total } \\
\text { Bacterial } \\
\text { colonies } \\
\text { before gargle } \\
(\mathrm{CFU} / \mathrm{ml})\end{array}$ & $\begin{array}{c}\text { Total } \\
\text { Bacterial } \\
\text { Colonies } \\
\text { after gargle } \\
(\mathrm{CFU} / \mathrm{ml})\end{array}$ & $\begin{array}{c}\text { Bacterial } \\
\text { colonies } \\
\text { total } \\
\text { decrease } \\
(\mathrm{CFU} / \mathrm{ml})\end{array}$ & $\begin{array}{c}\text { Total } \\
\text { Decrease of } \\
\text { Bacterial } \\
\text { Colonies in } \\
\text { Percent }(\%)\end{array}$ & $\begin{array}{c}\text { Total } \\
\text { Increase of } \\
\text { Bacterial } \\
\text { Colonies } \\
(\mathrm{CFU} / \mathrm{ml})\end{array}$ & $\begin{array}{c}\text { Total increase } \\
\text { of bacterial } \\
\text { colonies in } \\
\text { percent }(\%)\end{array}$ \\
\hline K3-1 & 120 & 0 & 120 & 100 & 0 & 0 \\
\hline $\mathrm{K} 3-2$ & 3000 & 0 & 3000 & 100 & 0 & 0 \\
\hline K3-3 & 20 & 0 & 20 & 100 & 0 & 0 \\
\hline K3-4 & 40 & 0 & 40 & 100 & 0 & 0 \\
\hline K3-5 & 3000 & 0 & 3000 & 100 & 0 & 0 \\
\hline
\end{tabular}

The observation result of the effectiveness of chitosan and calcium nanoparticle-based mouthwash formulations to the negative control and positive control, showed considerable differences occur. The use of mouthwash formulations based nanoparticles at concentrations of $250 \mathrm{ppm}, 500 \mathrm{ppm}$ and $750 \mathrm{ppm}$ can reduce the quantity of oral bacterial colonies ranges from $98-100 \%$ compared to the positive control and a negative control. (Tabel 6).

Table 6. Efficacy nanoparticles mouthwash in reducing quantity oral bacterial colony

\begin{tabular}{ccccccc}
\hline Treatment & $\begin{array}{c}\text { Mean of Total } \\
\text { Bacterial } \\
\text { colonies before } \\
\text { gargle }(\mathrm{CFU} / \mathrm{ml})\end{array}$ & $\begin{array}{c}\text { Mean of Total } \\
\text { Bacterial } \\
\text { Colonies after } \\
\text { gargle } \\
(\mathrm{CFU} / \mathrm{ml})\end{array}$ & $\begin{array}{c}\text { Bacterial } \\
\text { colonies } \\
\text { total } \\
\text { decrease } \\
(\mathrm{CFU} / \mathrm{ml})\end{array}$ & $\begin{array}{c}\text { Total } \\
\text { Decrease of } \\
\text { Bacterial } \\
\text { Colonies in } \\
\text { Percent }(\%)\end{array}$ & $\begin{array}{c}\text { Total } \\
\text { Increase of } \\
\text { Bacterial } \\
\text { Colonies } \\
(\mathrm{CFU} / \mathrm{ml})\end{array}$ & $\begin{array}{c}\text { Total } \\
\text { increase of } \\
\text { bacterial } \\
\text { colonies in } \\
\text { percent }(\%)\end{array}$ \\
\hline $\mathrm{N}$ & $293 \pm 125.49^{\mathrm{a}}$ & $165 \pm 75.40^{\mathrm{a}}$ & 128 & 44 & 0 & 0 \\
$\mathrm{P}$ & $158 \pm 58.33^{\mathrm{a}}$ & $8.33 \pm 3.37^{\mathrm{b}}$ & 145 & 92 & 0 & 0 \\
$\mathrm{~K} 1$ & $407 \pm 136.16^{\mathrm{a}}$ & $10 \pm 6.32^{\mathrm{b}}$ & 397 & 98 & 0 & 0 \\
$\mathrm{~K} 2$ & $88 \pm 27.27^{\mathrm{a}}$ & $0^{\mathrm{b}}$ & 88 & 100 & 0 & 0 \\
$\mathrm{~K} 3$ & $1236 \pm 720.34^{\mathrm{a}}$ & $0^{\mathrm{b}}$ & 1236 & 100 & 0 & 0 \\
\hline
\end{tabular}

\section{Discussion}

The oral health of children play a role in the growth and health of children. Poor oral conditions can lead to infection, pain, and loss of function that can affect communication, nutrition, learning activities, and other activities that are necessary for normal growth and development (Ogata et al., 2003). In addition to factors that exist in the mouth, such as the arrangement of teeth in the jaw, the acidity of saliva, tooth brushing habits, the amount and frequency of eating foods that cause caries, there are indirect factor called risk factors outside of, including, age, gender and the level of knowledge (Zhu et al., 2005). Distribution of oral conditions on the respondents in this study show the majority of children have high levels of good oral hygiene (52\%), moderate $(30 \%)$, and poor for $(18 \%)$. The results of this study are supported by study conducted by Sampakang et al., 2015 in SDN 47 Melonguane in North Sulawesi who obtained the prevalence of oral hygiene in children with good conditions by $54 \%$, moderate $43 \%$ and poor $3 \%$.
Analysis of the results of study on the relationship between sex and the level of oral hygiene resulted in the p-value $>0.05$ which showed no significant relationship between the level of oral hygiene by gender. The results of this study are supported by Joshi, suggested there was no association between caries with sex (Joshi et al., 2005), but according to the results of research conducted by Khan showed a significant relationship between sex with caries. The difference lies in the number of samples to be representative (Khan et al., 2001). Joshi conducting study on 60 men and 55 women who did not show significant correlation (Joshi et al., 2005), while Khan using a 251 men and 206 women as a sample, while Suwargiani, using 357 female and 224 male, both shows significant relationships (Khan et al., 2001).

The relationship between tooth brushing habits with the level of oral hygiene resulted in the p-value> 0.05 which showed no significant relationship between the level of oral hygiene by brushing teeth habits. The results of this study are supported by study conducted by Notohartojo and Andayasari, 2013, in Jakarta which 
claimed no correlation between the level of oral hygiene tooth and brushing habits. Relationships level of knowledge that includes time for brushing your teeth, lack dental visits to the level of oral hygiene shows the value of $p>0.05$, which showed no statistically significant association between oral hygiene with the level of knowledge. The results of the analysis of the respondents showed no relationship between the level of oral hygiene and sex, habits of brushing teeth, and the level of knowledge, it is because respondents who includes in this study less representative. In general, elementary school age children have high levels of poor oral hygiene, because of the lack of supervision of parents and teachers about how to consume sweet foods as well as the minimal level of knowledge the kids about how to maintain good oral hygiene. Dental and oral hygiene has been done by brushing teeth, but all that was not enough because the mouth has a complex environment and microflora, so the use of mouthwash is indispensable. Gargle with mouthwash can eliminate bacteria between teeth that are not reached by the toothbrush. The observation result of the bacterial colonies quantity result from gargle in negative control, positive control, and nanoparticle-based mouthwash formulations with a concentration of $250 \mathrm{ppm}, 500 \mathrm{ppm}$ and $750 \mathrm{ppm}$ respectively, overall showed a decline in the quantity of bacterial colonies. On the negative control showed a decrease in the number of bacterial colonies presentation ranges from $30 \%-73 \%$, with the lowest value of colony after gargling is $20 \mathrm{CFU} / \mathrm{ml}$ and the highest score is 460 $\mathrm{CFU} / \mathrm{ml}$. On the positive control showed a decrease ranging presentation $33 \%-100 \%$ with the lowest colony after rinsing by $10 \mathrm{CFU} / \mathrm{ml}$ and the highest $20 \mathrm{CFU} / \mathrm{ml}$. In nanoparticles-based mouthwash exhibit at a concentration of $250 \mathrm{ppm}$ range $95 \%-100 \%$ with the lowest colony after a rinse of $20 \mathrm{CFU} / \mathrm{ml}$ and the highest $30 \mathrm{CFU} / \mathrm{ml}$. Mouthwash with a concentration of $500 \mathrm{ppm}$ and $750 \mathrm{ppm}$ had a decrease in the number of colonies of $100 \%$, with the lowest and highest value of the colony after the rinse was $0 \mathrm{CFU} / \mathrm{ml}$. from the calculation of the colonies number on nanoparticle-based mouthwash showed a decrease in the number of bacterial colony is close to $100 \%$. However, a decrease in bacteria up to $100 \%$ (value 0 ) can also be caused due to an error or the amount of bacteria is less depleted (in saliva). However, the bacteria will grow again reach normal amount within a few hours to days, it was because the saliva affects the nutrients and growth factors needed by bacteria (Scannapieco, 1997). Comparison of the results of decrease in the number of saliva bacteria colonies in the negative control, positive control and nanoparticlesbsaed mouthwash formulations at concentrations of $250 \mathrm{ppm}, 500 \mathrm{ppm}$ and $750 \mathrm{ppm}$, resectively are presented in Table 6 shows the use of nanoparticles-based mouthwash have the high ability enough in reducing the quantity of oral bacterial colonies than with a negative control and a positive control, where the higher the concentration of mouthwash, higher the ability to reducing the quantity of salivary bacterial colonies. This proves that the modified-physical chitosan into nano chitosan has good efficacy in inhibiting the growth of bacteria. The particle size of nano chitosan has a greater adsorption capacity compared to micron chitosan because of its more small, so the touch pad with a substance to be absorbed was larger (Brigger et al., 2002). Chitosan can bind to lipids that exist on the surface of the bacterial cell wall. Gram-positive bacteria have a higher peptidoglycan content than gram-negative bacteria. High content of peptidoglycan which will lead to high lipid content. Chitosan can bind lipid polycationic, the destruction of the lipids in the bacterial cell wall will cause damage to the cell's defense (Cheung et al., 2015).

\section{Conclusion}

Based on the results and discussion of this study, chitosan and calcium nanoparticles-based mouthwash formulations have the ability to decrease the quantity of bacterial colonies in the oral cavity elementary school children. The higher concentration formulation of a mouthwash, the more it can decrease the quantity of oral bacterial colonies.

\section{Acknowledgements}

This study was supported by the Directorate General of Higher Education, Ministry of Education and Culture

\section{References}

Bansal, V., Sharma, P.K., Sharma, N., Pal, P.O., Malviya, R., 2011. Applications of chitosan and chitosan derivatives in drug delivery. Advances in Biological Research, 5(1), 28-37.

Batabyal, B., Chakraborty, S., Biswas, S., 2012. Role of the oral micro flora in human population: A brief review. Int. J. of Pharm. and Life Sci., 3(12), 2220-2227.

Brigger, I., Dubernet, C., Couvreur, P., 2002. Nanoparticles in cancer therapy and diagnosis. Adv. Drug Deliv. Rev., 54, 631-651.

Cheung, R.C.F., Ng, T.B., Wong, J.H., Chan W.Y., 2015. Chitosan: An update on potential. Mar., Drugs 2015, 13, 5156-5186.

Davis, G., 2001. The coconut Rhinoceros Beetle (Oryctes rhinocheos) with articular reference to the palau islands. Bernice P. Bishop Museum, Buletin, 212: 267-304.

Dorout, I.A., 2014. Oral bacterial interactions in periodontal health and disease. J. Den.Oral Hyg., 6(5),5157.

Farah, C.S., Mc Intosh, L., Mc Cullough, M.J., 2009. Mouthwashes. Australian Prescriber, 31(6),162-164. 
Goy, R.C., De Britto, D., Assis, O.B.G., 2009. A review of the antimicrobial activity of chitosan. Polímeros Sci. Tecnologia, 19(3),241-247.

Joshi, N., Rajesh, R., Sunitha, M., 2005. Prevalence of dental caries among school children in Kulasekharam village:acorrelated prevalence survey. J. Indian Soc. Pedod. Prev. Dent.,138-40.

Khan, N.B., Al Ghannam, N.A., Al Shammery, A.R., Wyne, A.H., 2001. Caries in primary school children: Prevalence, severity and pattern in Al-Ahsa, Saudi Arabia. Saudi Dental Journal, 13(2),71-74.

Klais, P.K., Mandar, M., Leibur, E., Marcotte, E., Hammarstrom, L., Mikelsaar, M.. 2005. Oral Lactobacilli in chronic periodontitis and periodontal health: species composition and antimicrobial activity. Oral Microbiology Immunology, 20,354-361.

Komariah, A., Astuti, L., 2012. Preparation and characterization of chitin contained in the exoskeletons of beetles Rhinoceros Beetle (Xylotrupes gideon L) and infestation of rice (Sitophilus oryzae L). Proceedings National Seminar of Biology IX. Faculty of Biology UNS, 648-654.

Law, V., Seow, W.K., Townsend, G., 2007. Factors influencing oral colonization of mutans streptococci in young children. Australian Dental J., 52(2),93-100.

Liu, G., Tang, C.M., Exley, R.M., 2012. Non-pathogenic Neisseria: members of an abundant, multi-habitat, diverse genus. Microbiology 161,1297-1312.

Majumdar, S., Singh, A.B., 2014. Normal microbial flora of oral cavity. J. of Adv. Medical and Dental Sci. Research, 2(4),62-66.

Mashima, I., Fujita, M., Nakatsuka, Y., Kado, T., Furuichi, Y., Herastuti, S., Nakazawa, F., 2015. The distribution and frequency of oral veillonella spp. associated with chronic periodontitis. Int. J. Curr. Microbiol. App. Sci., 4(3),150-160.

Mirhashemi, A.H., Bahador, A., Kassaee, M.Z., Daryakenari, G., Akhoundi, A.M., Sodagar, A., 2013. Antimicrobial effect of nano-zinc oxide and nano-chitosan particles in dental composite used in orthodontics. J. Med. Bacteriol, 2(3),1-10.

Notohartojo, I.T., Andayasari, L., 2013. Values of dental hygiene pulogadung industrial employees in Jakarta. Health Systems Research Bulletin, 16(2),168-175.
Puvvada, S., Vankayalapati, S., Sukhavasi, S., 2012. Extraction of chitin from chitosan from exoskeleton of shrimp for application in the pharmaceutical industry. International Current Pharmaceutical J., 1(9), 258-263.

Sampakang T, Paulina N, Gunawan J. Oral hygiene status of children aged 9-11 years and brushing the night before going to bed at SDN Melonguane. Jurnal e-GiGi (eG) 2015, $3(1), 1-4$.

Sarmento, B., Ribeiro, A., Veiga, F., Ferreira, D., Neufeld, R., 2007. Oral bioavailability of insulin contained in polysaccharide nanoparticles. Biomacromolecules, 8,30543060 .

Scannapieco, F.A., 1997. Saliva-bacterium interactions in oral microbial ecology. Critical Reviews in Oral Biology and Medicine, 5(4),203-248.

Schaeffer, L.M., Szewczyk, G., Nesta, J., Mark, V., Du-Thumm, L., Williams, I., Arvanitidou, E.. 2011. In vitro antibacterial efficacy of cetylpyridinium chloride-containing mouthwashes. Clin. Dent., 22,183-186.

Stern, S.T., McNeil, S.C., 2008. Nanotechnology safety concerns revisited. Toxilogical Sci.,101(1), 4-21.

Sun, K., Li, Z.H., 2013. Preparations, properties and applications of chitosan based nanofibers fabricated by electrospinning. express Polymer Letters, 5(4),342-361.

Tiyaboonchai, W., 2003. Chitosan nanoparticles : A promising system for drug delivery. Naresuan University J.,11(3), 51-66.

Yah, C.S., Iyuke, S.E., Simate, G.S., 2012. Nanoparticles toxicity and their routes of exposures. Iranian J. Pharmaceutical Sci.,25, 477-491.

Yamaguchi, M., Terao, Y., Ogawa, T., Takahashi, T., Hamada, S., Kawabata, S., 2006. Role of Streptococcus sanguinis sortase in bacterial colonization. Microbes and Infection, 8,2791-2796.

Yogeshkumar,G., Atul, G., Adhikrao, Y., 2013. Chitosan and Its applications: A review of literature. International J. Res. Pharmaceutical and Biomedical Sci., 4(1),312-333.

Zhu, L., Petersen, P.E., Wang, H.Y., Bian, J.Y., Zhang, B.X., 2005. Oral health knowledge, attitudes and behaviour of adults in China. Int. Dent. J., 55, 231-241.

Ogata, B., Trahms, C., 2003. Nutrition and oral health for children. Nutrition Focus, 18(6),1-10.

How to cite this manuscript: Ade Komariah, Roberto A Tatara, Del A Bustami. Efficacy of Rhinoceros Beetle (Xylotrupes Gideon) Nano Chitosan and Calcium Mouthwash in Reducing Quantity Oral Cavity Bacteria among Elementary School Age Children. International Journal of Advanced Biological and Biomedical Research 5(1), 2017, 41-47. DOI: 10.18869/IJABBR.2017.405. 